\title{
Bond strength of adhesive systems to human tooth enamel
}

\author{
Resistência adesiva de sistemas adesivos ao \\ esmalte dentário humano
}

\section{Thaís Cachuté Paradella(a) Marcelo Fava ${ }^{(b)}$}

(a) Doctorate Student, Department of Bioscience and Oral Diagnosis; (b) Pediatric Dentistry Professor, Department of Social Dentistry and Children's Clinic - School of Dentistry of São José dos Campos, São Paulo State University.

\section{Corresponding author: \\ Thaís Cachuté Paradella \\ Rua Padre Rodolfo, 71 - Vila Ema \\ São José dos Campos - SP - Brazil CEP: 12243-080 \\ E-mail: tparadella@yahoo.com}

Received for publication on Jun 15,2006 Sent for alterations on Sep 13, 2006

Accepted for publication on Oct 05, 2006

\begin{abstract}
The purpose of this study was to evaluate in vitro three adhesive systems: a total etching single-component system (G1 Prime \& Bond 2.1), a self-etching primer (G2 Clearfil SE Bond), and a self-etching adhesive (G3 One Up Bond F), through shear bond strength to enamel of human teeth, evaluating the type of fracture through stereomicroscopy, following the ISO guidance on adhesive testing. Thirty sound premolars were bisected mesiodistally and the buccal and lingual surfaces were embedded in acrylic resin, polished up to 600 -grit sandpapers, and randomly assigned to three experimental groups $(\mathrm{n}=20)$. Composite resin cylinders were added to the tested surfaces. The specimens were kept in distilled water $\left(37^{\circ} \mathrm{C} / 24 \mathrm{~h}\right)$, thermocycled for 500 cycles $\left(5^{\circ} \mathrm{C}-55^{\circ} \mathrm{C}\right)$ and submitted to shear testing at a crosshead speed of $0.5 \mathrm{~mm} / \mathrm{min}$. The type of fracture was analyzed under stereomicroscopy and the data were submitted to Anova, Tukey and Chi-squared (5\%) statistical analyses. The mean adhesive strengths were G1: $18.13 \pm 6.49 \mathrm{MPa},(55 \%$ of resin cohesive fractures); G2: $17.12 \pm 5.80 \mathrm{MPa}$ (90\% of adhesive fractures); and G3: $10.47 \pm 3.14 \mathrm{MPa}$ ( $85 \%$ of adhesive fractures). In terms of bond strength, there were no significant differences between G1 and G2, and G3 was significantly different from the other groups. G1 presented a different type of fracture from that of G2 and G3. In conclusion, although the total etching and self-etching systems presented similar shear bond strength values, the types of fracture presented by them were different, which can have clinical implications.
\end{abstract}

Descriptors: Shear strength; Dentin-bonding agents; Dental enamel.

Resumo: O objetivo deste estudo foi avaliar in vitro três sistemas adesivos: um monocomponente com condicionamento ácido total (G1 Prime \& Bond 2.1), um "primer" autocondicionante (G2 Clearfil SE Bond) e um adesivo autocondicionante (G3 One Up Bond F), através de resistência ao cisalhamento ao esmalte de dentes humanos, avaliando o tipo de fratura por estereomicroscopia, seguindo as normas ISO para testes adesivos. Trinta prémolares hígidos foram seccionados ao meio em sentido mésio-distal, incluídos em resina acrílica, polidos até lixa d'água de granulação 600 e aleatoriamente divididos em três grupos $(n=20)$. Cilindros de resina composta foram adicionados às superfícies de teste. Os espécimes foram armazenados em água destilada $\left(37^{\circ} \mathrm{C} / 24 \mathrm{~h}\right)$, termociclados por 500 ciclos $\left(5^{\circ} \mathrm{C}-55^{\circ} \mathrm{C}\right)$ e submetidos ao teste de cisalhamento com velocidade de $0,5 \mathrm{~mm} / \mathrm{min}$, sendo o tipo de fratura analisado sob estereomicroscopia e os dados submetidos à análise estatística Anova, Tukey e Qui-quadrado (5\%). As médias de resistência adesiva foram: G1: $18,13 \pm 6,49 \mathrm{MPa},(55 \%$ de fraturas coesivas em resina); G2: 17,12 $\pm 5,80 \mathrm{MPa}(90 \%$ de fraturas adesivas) e G3 10,47 $\pm 3,14 \mathrm{MPa}$ (85\% de fraturas adesivas). Em termos de resistência adesiva, não houve diferenças significantes entre G1 e G2, tendo G3 apresentado diferença significante em relação aos demais grupos. G1 apresentou tipo de fratura diferente de G2 e G3. Em conclusão, apesar de os sistemas adesivos com condicionamento ácido total e "primer" autocondicionante terem apresentado valores de resistência adesiva similares, o tipo de fratura apresentado por eles foi diferente, o que pode ter implicações clínicas.

Descritores: Resistência ao cisalhamento; Adesivos dentinários; Esmalte dentário. 


\section{Introduction}

Modern dentistry treatments are based on minimal tooth wear due to adhesive techniques and current aesthetic restorative materials. The enamel etching concept has been improved through the years, and new adhesive systems have been released and researched. . $^{2,3,42,13,19}$

Resin adhesion to acid etched enamel is mainly due to the formation of resin tags. Acid etching removes nearly $10 \mu \mathrm{m}$ of enamel surface and creates a 5 to $50 \mu \mathrm{m}$ deep porous layer. This irregular surface is the result of hydroxyapatite crystals dissolution. Therefore, when a low-viscosity resin is applied, it penetrates into the microporosities and polymerizes to form a micromechanical bond with enamel. Hydrophilic adhesives have been marketed in the form of multiple-bottle or single-component systems, but both with separate conditioner. Nonetheless, selfetching systems, which include self-etching primers and self-etching adhesives, were developed in order to simplify and eliminate clinical steps. However, it is important that these simplifications do not affect enamel adhesion. ${ }^{7}$

The bond strength provided by adhesive systems is the force per unit of area required to break a bonded assembly with failure occurring in or near the adhesive surface. The purpose of either a tensile, microtensile or shear bond strength test is to establish a numeric value in order to determine how strong that bond was. ${ }^{3,18,22}$ Shear testing is important since it presents reliable results and because shear stress is more representative in a clinical situation. ${ }^{3,18}$ In 1994, the International Organization for Standardization (ISO) ${ }^{11}$ presented guidance on adhesive testing in order to standardize adhesion tests so that in vitro studies could provide similar, relevant and reproducible results that would support in vivo testing. ${ }^{20}$

The purpose of this study was to evaluate in vitro three adhesive systems: a total etching adhesive system, a self-etching primer and a self-etching adhesive, through shear bond strength to enamel of human teeth, evaluating the type of fracture through stereomicroscopy, following the $\mathrm{ISO}^{11}$ guidance on adhesive testing. The working hypothesis was that there would be no significant differences between total etching and self-etching adhesives regarding shear bond strength and type of fracture after debonding.

\section{Material and Methods}

The methodology applied in this study was approved by the Ethics Committee, State University of São Paulo (Protocol \# 067/2003-PH/CEP). Thirty premolars, extracted due to orthodontic reasons, from 14-16 year-old patients, were kept in a $0.5 \%$ chloramine solution, for no longer than a week. After this period of time, the teeth were kept in distilled water at $4^{\circ} \mathrm{C}$, for no longer than 6 months, with a weekly change of water. ${ }^{11}$ The teeth's crowns were analyzed under stereomicroscopy (Zeiss/Stemi 2000C-MC-80-DX, Berlin, Germany) and the teeth with visible cracks or enamel alterations were eliminated from the study.

The samples were bisected mesiodistally with a high-speed diamond saw (KG Sorensen, Reference 7020, São Paulo, SP, Brazil), under air/water cooling, and the buccal and lingual surfaces were embedded in acrylic resin, polished up to 600-grit sandpapers, until a flat enamel area of $5 \mathrm{~mm}$ in diameter was exposed. ${ }^{4,5,9,14,17}$. The specimens were randomly assigned to three experimental groups $(n=20)$ : $G 1$ : Prime \& Bond 2.1 (Dentsply Ind., Rio de Janeiro, RJ, Brazil) total etching single-component system, G2: Clearfil SE Bond (Kuraray Medical Inc., Tokyo, Japan) self-etching primer, and G3: One-Up Bond F (Tokuyama Dental Corp., Tokyo, Japan) self-etching adhesive system. The adhesive system's testing area was delimited using a circular adhesive tape with a 4 -mm diameter central orifice. ${ }^{13,14}$ The adhesive systems were used according to the manufacturers' instructions described in Table 1. A teflon mould (4 mm x $5 \mathrm{~mm}$ ) was used to build resin cylinders (Z-250 3M ESPE Dental Products Division, St. Paul, MN, USA) on the test surface. The material was light-cured for 40 seconds using a XL3000 light-curing device (3M ESPE Dental Products, St. Paul, MN, USA), with $400 \mathrm{~mW} / \mathrm{cm}^{2}$ of light intensity.

The specimens were then stored in distilled water at $37^{\circ} \mathrm{C}$ for $24 \mathrm{~h}$, thermocycled for 500 cycles $\left(5^{\circ} \mathrm{C}\right.$ $55^{\circ} \mathrm{C}$ ) and submitted to shear testing in a universal 
Table 1 - Description of the adhesive systems.

\begin{tabular}{c|l|l|l|l}
\hline Group & Adhesive system & \multicolumn{1}{|c|}{ Main characteristic } & \multicolumn{1}{|c}{ Manufacturer/Batch number } & \multicolumn{1}{c}{ Procedures } \\
\hline G1 & Prime \& Bond 2.1 & $\begin{array}{l}\text { Total etching } \\
\text { single-component }\end{array}$ & $\begin{array}{l}\text { Dentsply Ind., Rio de Janeiro, RJ, Brazil } \\
450106 / 2005\end{array}$ & $\begin{array}{l}\text { Acid etching: 15 s; } \\
\text { Rinsing: 15 s; } \\
\text { Apply two layers; Light-curing: 10 s. }\end{array}$ \\
\hline G2 & Clearfil SE Bond & $\begin{array}{l}\text { Self-etching } \\
\text { primer }\end{array}$ & $\begin{array}{l}\text { Kuraray Medical Inc., Tokyo, Japan } \\
\text { 00405A 08/2005 }\end{array}$ & $\begin{array}{l}\text { Apply primer, wait 20 s, apply bond, } \\
\text { light-curing: 10 s. }\end{array}$ \\
\hline G3 & One Up Bond F & $\begin{array}{l}\text { Self-etching } \\
\text { adhesive system }\end{array}$ & $\begin{array}{l}\text { Tokuyama Dental Corp., Tokyo, Japan } \\
096 \mathrm{M} \mathrm{01/2007}\end{array}$ & $\begin{array}{l}\text { Mix bonding A with bonding B; Apply, wait } \\
20 \mathrm{~s} \text {, light-curing: } 10 \mathrm{~s} .\end{array}$ \\
\hline
\end{tabular}

Table 2 - Description of the results regarding shear bond strength values (MPa)

\begin{tabular}{l|r|r|r}
\hline \multicolumn{1}{c|}{ Statistics } & G1 & \multicolumn{1}{c|}{ G2 } & \multicolumn{1}{c}{ G3 } \\
\hline Mean & 18.13 & 17.12 & 10.47 \\
\hline Standard Deviation & 6.49 & 5.80 & 3.14 \\
\hline Variation coefficient & 35.80 & 33.89 & 30.07 \\
\hline Minimum value & 10.71 & 8.03 & 5.68 \\
\hline Maximum value & 34.75 & 26.48 & 16.12 \\
\hline
\end{tabular}

testing machine (Instron, model 411, Chicago, IL, USA) set to operate at a $0.5 \mathrm{~mm} / \mathrm{min}$ crosshead speed until breakdown. The specimens were positioned in a stainless steel mould in order to maintain a $90^{\circ}$ angle in relation to the applied force. ${ }^{10,11,18}$

The obtained data $\left(\mathrm{kgf} / \mathrm{cm}^{2}\right)$ was transformed in $\mathrm{MPa}$ and submitted to parametric statistical analysis, ANOVA and Tukey (5\%). The null hypothesis $\left(\mathrm{H}_{0}\right)$ was that there would be no difference between the tested adhesives. After shear bond strength testing, the specimens had their types of fractures analyzed under stereomicroscopy. Fractures were classified as either adhesive, cohesive (resin or enamel) or mixed fractures ${ }^{12}$, and the data were submitted to Chi-squared $\left(\chi^{2}\right)$ statistical analysis.

\section{Results}

The results and statistical findings for the three studied groups regarding shear bond strength are presented in Table 2. According to the values obtained in this study, it was possible to notice that the standard deviations for the three groups were close and the variation coefficients were inferior to $50 \%$, which justifies a parametric statistical analysis. According to ANOVA testing, the mean values differed statistically ( $\mathrm{p}=0.001$ at a confidence level of $95 \%$ ),

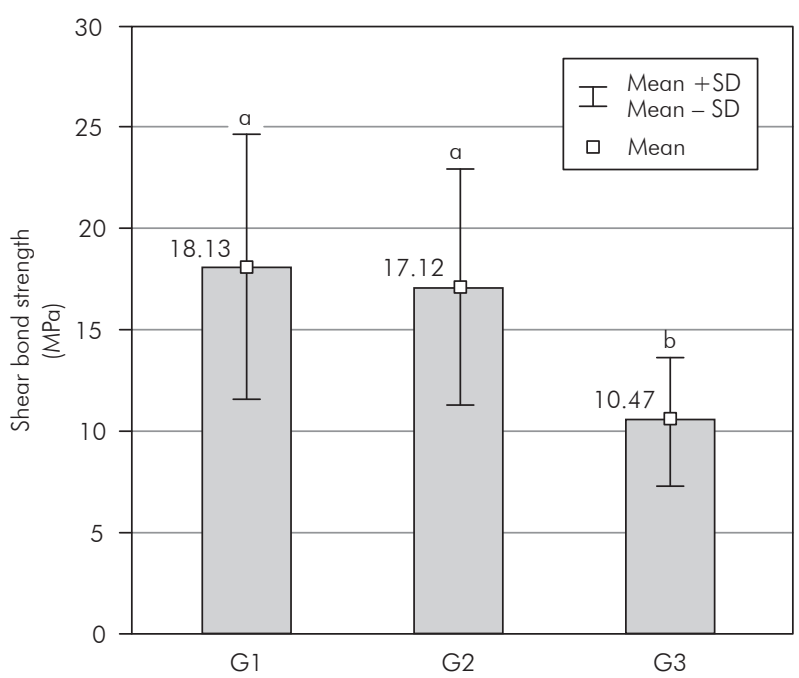

Graph 1 - Box chart display of the results after Tukey's test. Similar letters (a) indicate same statistical group. Different letters (b), different statistical findings.

so $\mathrm{H}_{0}$ was rejected. With post-hoc Tukey's multiple comparison test, the formation of two groups with same bond strength values was possible, as shown in Graph 1. Statistical analysis showed no significant differences between G1 and G2. Only G3 showed significant statistical difference in relation to both G1 and G2.

Regarding type of fracture, the results are presented in Table 3, which shows that G1 presented a higher number of resin cohesive fractures, whereas G2 and G3 presented a higher number of adhesive fractures. These data were submitted to Chi-squared $\left(\chi^{2}\right)$ statistical analysis, at a $5 \%$ level of confidence, which evaluated the equality or similarity of mutually exclusive discrete categories. This means that this statistical analysis would either confirm or not the similarity of the type of fracture presented by the studied groups. The results of the Chi-squared 
statistical analysis are presented in Table 3 and Table 4 .

Analyzing the data in Table 3, when the three experimental groups are considered, the Chi-squared value $\left(\chi^{2}=39.6\right)$ is higher than the Chi-squared critical value (12.5). Therefore, it was concluded that there was significant statistical difference between the types of fracture observed in G1, G2 and G3. In a second analysis, presented in Table 4, there is no significant statistical difference between the selfetching systems (G2 and G3), since $\chi^{2}=3.0$, which is lower than the $\chi^{2}$ critical value (7.8).

\section{Discussion}

Researches involving adhesive systems have become frequent in dentistry, since in vitro adhesive testing is simple and fast. However, adhesive testing must be performed in a standard manner, so that its results can be trustworthy. ${ }^{3,11,18,20}$. ISO ${ }^{11}$ guidance on adhesive testing standardizes adhesion testing, detailing how tests should be performed. Although in vitro tests do not completely predict how dental

Table 3 - Chi-squared $\left(\chi^{2}\right)$ statistical analysis of the type of fracture by groups individually.

\begin{tabular}{l|r|r|r|r|r|r|r}
\hline \multirow{2}{*}{ Type of fracture } & \multicolumn{2}{|c|}{$\mathrm{G} 1$} & \multicolumn{2}{c|}{$\mathrm{G} 2$} & \multicolumn{2}{c|}{$\mathrm{G} 3$} & \multirow{2}{*}{$\chi^{2}$} \\
\cline { 2 - 8 } & $\mathrm{n}$ & $\%$ & $\mathrm{n}$ & $\%$ & $\mathrm{n}$ & $\%$ & \\
\hline Adhesive & 1 & 5 & 18 & 90 & 17 & 85 & 15.1 \\
\hline Enamel cohesive & 3 & 15 & 1 & 5 & 1 & 5 & 1.6 \\
\hline Resin cohesive & 11 & 55 & 0 & 0 & 2 & 10 & 15.8 \\
\hline Mixed & 5 & 25 & 1 & 5 & 0 & 0 & 7.0 \\
\hline & 20 & 100 & 20 & 100 & 20 & 100 & 39.6 \\
\hline
\end{tabular}

$\chi^{2}$ critical value $=12.5$. materials will behave in the oral cavity, these tests are valuable. Due to the quick development and release of new bonding agents, it has become necessary to find simple and fast methods to evaluate the effectiveness of these new agents, since clinical trials are time- and money-consuming. In vitro testing represents an effective and fast way to evaluate dental materials. ${ }^{14,20,23}$

In this study, the $\mathrm{ISO}^{11}$ guidance on adhesive testing was used for storage of the test specimens, stain rate for bond breaking, treatment of results and accelerated ageing through thermocycling, which is also important in bond testing since its effects are valuable parameters in determining the stability of adhesive bonding agents, because it simulates intraoral conditions. ${ }^{14,16}$. The purpose of these procedures was not only to standardize the study, but also to maximally simulate oral conditions.

The shear bond strength values of acid etched enamel in association with single-component adhesive systems are in the range of $20 \mathrm{MPa} .{ }^{1}$ The results in this study regarding G1 are lower than those presented by Gordan et al. ${ }^{6}$ (1998), which found bond strength values of $27.2( \pm 6.22) \mathrm{MPa}$. However, no thermocycling was performed. Thermocycling can lower bonding values, since hot water accelerates hydrolysis ${ }^{14}$ although this is a matter of discussion in literature. A recent study, ${ }^{1}$ which evaluated bond strength after 10,000 thermal cycles with various adhesive systems, concluded that the mean bond strengths remained unchanged after thermal stress. On the other hand, another recent study ${ }^{8}$ using human teeth found higher mean bond strength values for Clearfil SE Bond after 24 hours (23.4 MPa) than

Table 4 - Chi-squared statistical analysis $\left(\chi^{2}\right)$ of the type of fracture considering every two groups.

\begin{tabular}{|c|c|c|c|c|c|c|c|c|c|}
\hline \multirow{2}{*}{ Type of fracture } & \multicolumn{3}{|c|}{ G1/G2 } & \multicolumn{3}{|c|}{ G1/G3 } & \multicolumn{3}{|c|}{ G2/G3 } \\
\hline & $n(G 1)$ & $\mathrm{n}(\mathrm{G} 2)$ & $\chi^{2}$ & $n(G 1)$ & $n(G 3)$ & $\chi^{2}$ & $\mathrm{n}(\mathrm{G} 2)$ & $n(G 3)$ & $\chi^{2}$ \\
\hline Adhesive & 1 & 18 & 15.2 & 1 & 17 & 14.2 & 18 & 17 & 0.0 \\
\hline Enamel cohesive & 3 & 1 & 1.0 & 3 & 1 & 1.0 & 1 & 1 & 0.0 \\
\hline Resin cohesive & 11 & 0 & 11.0 & 11 & 2 & 6.2 & 0 & 2 & 2.0 \\
\hline \multirow[t]{2}{*}{ Mixed } & 5 & 1 & 2.6 & 5 & 0 & 5.0 & 1 & 0 & 1.0 \\
\hline & 20 & 20 & 29.8 & 20 & 20 & 26.4 & 20 & 20 & 3.0 \\
\hline
\end{tabular}

$\chi^{2}$ critical value $=7.8$. 
in the present study, and thermocycling was not performed. Further studies should be performed in order to establish the effect of thermocycling on bond strength.

Torii et al. ${ }^{22}$ (2002) found similar bond strength values with the same self-etching adhesive system used in G2 of the present study. However, bovine teeth were used, and although many studies regarding bond strength include bovine teeth as substitutes for human teeth, with no statistical differences between bovine and human enamel, ${ }^{13}$ the enamel surface of bovine teeth presents differences when compared to that of human teeth and, therefore, human teeth should be preferable when available. ${ }^{11}$ Moura et al. ${ }^{15}$ (2006), using micro-tensile bond strength testing, evaluated different adhesive systems and their results corroborate the findings of the present study as they found a similar mean bond strength $(18.7 \mathrm{MPa})$ for Clearfil SE. The authors also stated that an overall increase in porosity was evident along the entire enamel surface treated with the self-etching primers, concluding that no selective demineralization similar to that produced with $35 \%$ phosphoric acid was observed, and that the highest bond strength means and the more retentive etching pattern were observed for the total etching adhesives. Regarding the self-etching systems tested, the authors stated that Clearfil SE Bond should be preferred. Although in the present study Clearfil SE Bond presented higher mean bond strengths than One Up Bond F, no statements can be made regarding the demineralization pattern produced by the adhesive systems since scanning electron microsco-

\section{References}

1. Asaka Y, Yamaguchi K, Inage H, Takamizawa T, Kurokawa $\mathrm{H}$, Rikuta A et al. Effect of thermal cycling on bond strengths of single-step self-etch adhesives to bovine dentin. J Oral Sci. 2006;48(3):63-9.

2. Bishara SE, Soliman M, Lafoon J, Warren JJ. Effect of changing a test parameter on the shear bond strength of orthodontic brackets. Angle Orthod. 2005;75(5):832-5.

3. Cardoso PEC, Braga RR, Carrilho MRO. Evaluation of microtensile, shear and tensile tests determining the bond strength of three adhesive systems. Dent Mater. 1998;14(6):394-8. py (SEM) was not performed for all the samples.

In the present study, the self-etching systems presented a greater number of adhesive fractures when compared to the total etching single-component systems. There is not a consensus in the literature regarding the type of fracture after bonding tests. Toledano et al. ${ }^{21}$ (2001) found $50 \%$ of adhesive fractures and $50 \%$ of mixed fractures with the same adhesive system used in G2. However, Fritz et al. ${ }^{5}$ (2001) found $60 \%$ of enamel-cohesive fractures, and, in Miyazaki et al. ${ }^{14}$ (2002), a tendency of mixed and cohesive fractures was observed when this system was used.

It has been reported that when an adhesive fracture occurs, enamel bonding has not been well-established. ${ }^{7}$ Thus, in orthodontics, the use of self-etching systems is being encouraged since it promotes adhesive fractures when the bracket is removed, preventing enamel loss..$^{2,24,25}$ Therefore, the type of fracture after debonding can have clinical implications. However, parameters need to be taken into consideration for interstudy comparison of in vitro results ${ }^{2,10}$ and further standardized studies should be performed in order to corroborate the findings of the present study.

\section{Conclusion}

The total etching adhesive system Prime \& Bond 2.1 and self-etching primer Clearfil SE Bond both presented acceptable shear bond strength values. However, the types of fracture presented by the selfetching systems were different from those presented by the total etching system, since the self-etching systems presented mostly adhesive fractures.

4. Di Hipolito V, de Goes MF, Carrilho MR, Chan DC, Daronch M, Sinhoreti MA. SEM evaluation of contemporary self-etching primers applied to ground and unground enamel. J Adhes Dent. 2005;7(3):203-11.

5. Fritz UB, Diedrich P, Finger WJ. Self-etching primers - an alternative to the conventional acid etch technique? J Orofac Orthop. 2001;62(3):238-45.

6. Gordan VV, Boyer D, Söderhold K-J. Enamel and dentin shear bond strength of two resin modified glass ionomer and two resin based adhesives. J Dent. 1998;26(5):497-503. 
7. Hara AT, Amaral CM, Pimenta LAF, Sinhoreti MAC. Shear bond strength of hydrophilic adhesive systems to enamel. Am J Dent. 1999;12(4):181-4.

8. Kanehira M, Finger WJ, Hoffmann M, Endo T, Komatsu M. Relationship between degree of polymerization and enamel bonding strength with self-etching adhesives. J Adhes Dent. 2006;8(4):211-6.

9. Kanemura N, Sano H, Tagami J. Tensile bond strength to and SEM evaluation of ground and intact enamel surfaces. J Dent. 1999;27(7):523-30.

10. Klocke A, Kahl-Nieke B. Influence of force location in orthodontic shear bond strength testing. Dent Mater. 2005;21(5):391-6.

11. International Organization for Standardization. TR 11405. Dental Materials - Guidance on testing of adhesion to tooth structure. 1994;1-15.

12. Jain P, Stewart GP. Effect of dentin primer on shear bond strength of composite resin to moist and dry enamel. Oper Dent. 2000;25(1):51-8.

13. Lopes MB, Sinhoreti MAC, Sobrinho LC, Consani S. Comparative study of the dental substrate used in shear bond strength tests. Pesqui Odontol Bras. 2003;17(2):171-5.

14. Miyazaki M, Kinoura K, Honjo G, Onose H. Effect of selfetching primer application method on enamel bond strength. Am J Dent. 2002;15(2):412-6.

15. Moura SK, Pelizzaro A, Dal Bianco K, de Goes MF, Loguercio $\mathrm{AD}$, Reis A et al. Does the acidity of self-etching primers affect bond strength and surface morphology of enamel? J Adhes Dent. 2006;8(2):75-83.

16. Nikaido T, Kuzelmann K-H, Chen H, Ogata M, Harada N, Yamaguchi $S$ et al. Evaluation of thermal cycling and mechani- cal loading on bond strength of a self-etching primer system to dentin. Dent Mater. 2002;18(6):269-75.

17. Oberländer H, Friedl K-H, Schmalz G. Bond strength of polyacid-modified resins using a new one-step adhesive system. Oper Dent. 2001;26(4):127-33.

18. Oilo G. Bond strength testing - what does it mean? Int Dent J. 1993;43(5):492-8.

19. Salz U, Zimmermann J, Zeuner F, Moszner N. Hydrolitic stability of self-etching adhesive systems. J Adhes Dent. 2005;7(2):107-16.

20. Stanley HR. Guest editorial: an urgent plea for standardized bonding adhesion test. J Dent Res. 1993;72(1):1362-3.

21. Toledano M, Osorio R, Leonardi G, Rosales-Leal JI, Ceballos L, Cabrerizo-Vilchez MA. Influence of self-etching primer on the resin adhesion to enamel and dentin. Am J Dent. 2001;14(5):205-10.

22. Torii Y, Itou K, Hikasa R, Iwata S, Nishitani Y. Enamel tensile bond strength and morphology of resin-enamel interface created by acid etching system with or without moisture and self-etching priming system. J Oral Rehabil. 2002;29(6):528 33.

23. Torii Y, Itou K, Nishitani Y, Yoshiyama M, Ishikawa K, Suzuki $\mathrm{K}$. Effect of self-etching primer containing $\mathrm{N}$-acryloyl aspartic acid on enamel adhesion. Dent Mater. 2003;19(4):253-8.

24. Vicente A, Bravo LA, Romero M, Ortiz AJ, Canteras M. Shear bond strength of orthodontic brackets bonded with self-etching primers. Am J Dent. 2005;18(4):256-60.

25. Yamada R, Hayakawa T, Kasai K. Effect of using self-etching primer for bonding orthodontic brackets. Angle Orthod. 2002;72(4):558-64.

\section{ERRATUM}

In the article "In vitro evaluation of the antimicrobial activity of endodontic sealers", by authors Daniela Cristina Miyagak, Elaine Manso Oliveira Franco de Carvalho, Carlos Roberto Colombo Robazza, Jorge Kleber Chavasco and Gustavo Labegalline Levorato, published in Brazilian Oral Research, volume 20, number 4, oct/dec, 2006, pages 303-6, references 19 and 20 were published with errors. The correct data of these references are as follows:

19. Tronstad L, Andreasen JO, Hasselgren G, Kristerson L, Riis I. pH changes in dental tissues after root canal filling with calcium hydroxide. J Endod. 1980;7:17-21.

20. Waltimo TMT, Siren EK, Torkko HLK, Olsen I, Haapasalo MPP. Fungi in therapy-resistant apical periodontitis. Int Endod J. 1997;30:96-101. 